\title{
The Chemical Control of Tobacco Black Root Rot*
}

\author{
by Rene Delon and Mwfidi-Nitu Pululu
}

Institut du tabac, Societé nationale d'exploitation industrielle des tabacs et allumettes (SEITA), Bergerac, France

\section{SUMMARY}

With the development of flue-cured and Burley tobacco culture in France, black root rot, caused by Chalara elegans (Thielaviopsis basicola), is becoming a problem.

Since 1981 the Bergerac Tobacco Institute has studied the efficacy of new endotherapeutic fungicides of the triazole family. Among these, triadimenol was found to be the most effective. The treatment method consists of spraying tobacco plants with a triadimenol solution 48 to 72 hours before transplanting. This method appears to be an economic and efficient means to control tobacco black root rot in the field.

Treatment of young tobacco plants with triadimenol strongly stimulates rhizogenesis and this favors strengthening of the tobacco plants in the field.

\section{ZUSAMMENFASSUNG}

Mit dem fortschreitenden Anbau heller Tabaktypen wie Virgin und Burley in Frankreich stellt sich in zunehmendem Maße das Problem der damit verbundenen Ausbreitung der Wurzelbräune, eine durch Cbalara elegans (Thielaviopsis basicola) verursachte Pilzerkrankung.

Seit 1981 sind im Forschungsinstitut in Bergerac neue endotherapeutische Fungizide der Triazol-Klasse auf

\footnotetext{
* Received: 11th June 1986 - accepted: 14th June 1988.

Presented at the 8th International Tobacco Science Congress (COkEstA) held in Viensa, Austria, in 1984.
}

ihre Wirksamkeit hin untersucht worden, wobei sich Triadimenol als am geeignetsten erwies. Die Applikation erfolgte dabei durch Besprühen der Tabakpflanzen mit einer Triadimenol-Lösung 48 bis 72 Stunden vor dem Auspflanzen. Es handelt sich um eine einfach anwendbare, wirksame und wirtschaftliche Feldmethode zur Bekämpfung der Wurzelbrāune bei Tabakpflanzen.

Die Behandlung junger Tabakpflanzen mit Triadimenol regt die Wurzelbildung stark an, was zur Kräftigung der Pflanze beiträgt.

\section{RESUME}

Avec le développement des variêtés de tabacs clairs (Virginie et Burley), la pourriture noire des racines provoquée par Chalara elegans (Thielaviopsis basicola) redevient en France un problème d'actualité.

Depuis 1981, l'Institut de Bergerac étudie l'efficacité de nouveaux fongicides endothérapiques de la classe des triazoles. Parmi eux, le triadiménol s'est révélé le plus intéressant. Une méthode de lutte envisageant le traitement par arrosage du tabac en pépinière avec une solution de triadiménol 48 à 72 heures avant la transplantation est proposée. Cette technique apparaît comme un moyen simple, économique et efficace pour lutter contre la pourriture noire des racines du tabac en plein champ.

Le traitement des jeunes plantes de tabac par le triadiménol stimule fortement la rhizogenèse, et cela favorise la reprise du tabac. 
Figure 1. Drenching of the seedlings before transplanting.

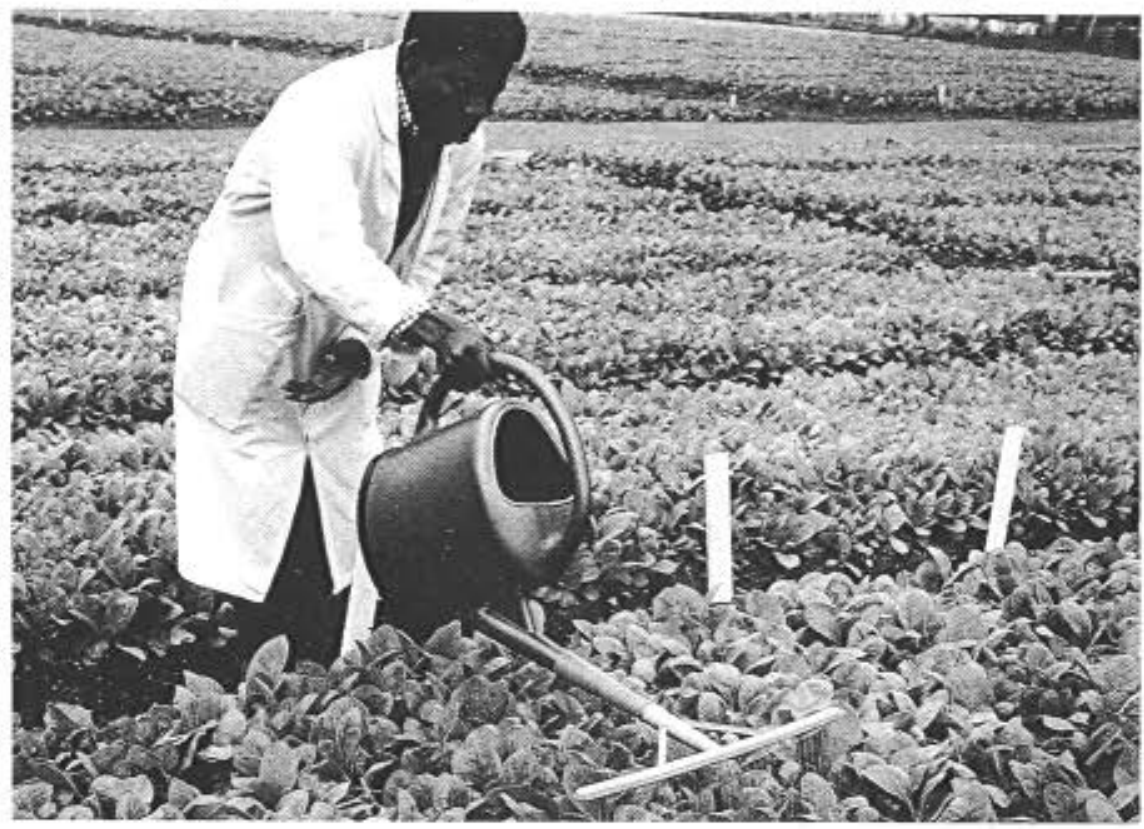

Figure 2.

Phytotoxicity study: comparison 29 days after fungicide treatment between the control and treatment with $3 \mathrm{~g}$ triadimenol a.i. $/ \mathrm{m}^{2}$.

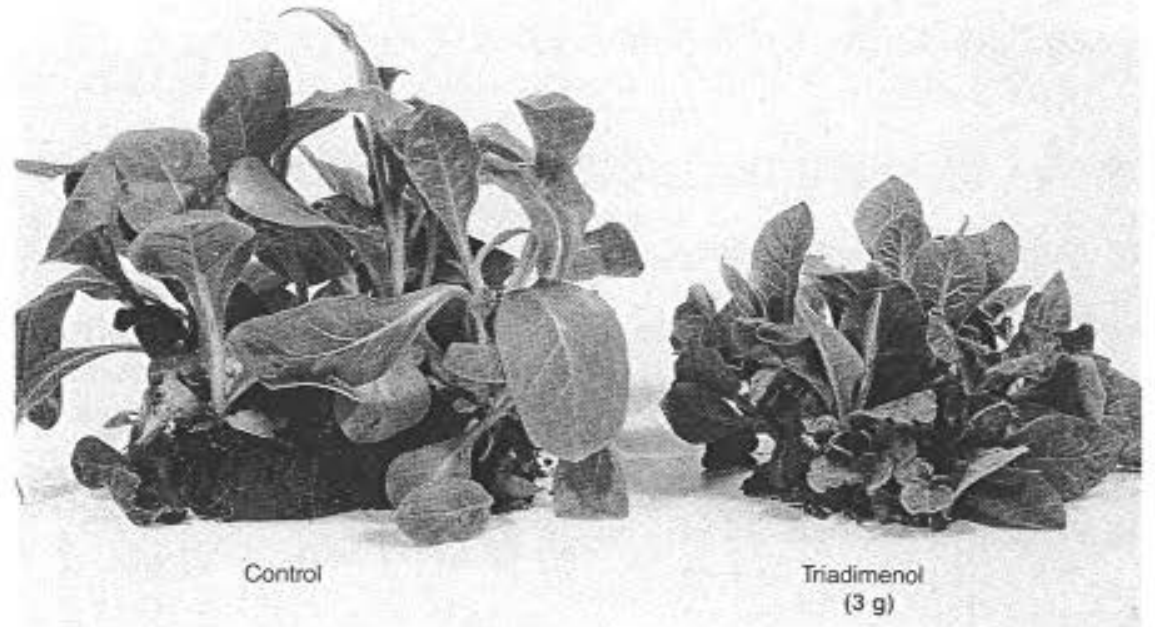

Figure 3.

Detail of leaf deformations caused by a high dose of triadimenol $\left(3 \mathrm{~g}\right.$ a.i. $\left./ \mathrm{m}^{2}\right) 29$ days after fungicide treatment.

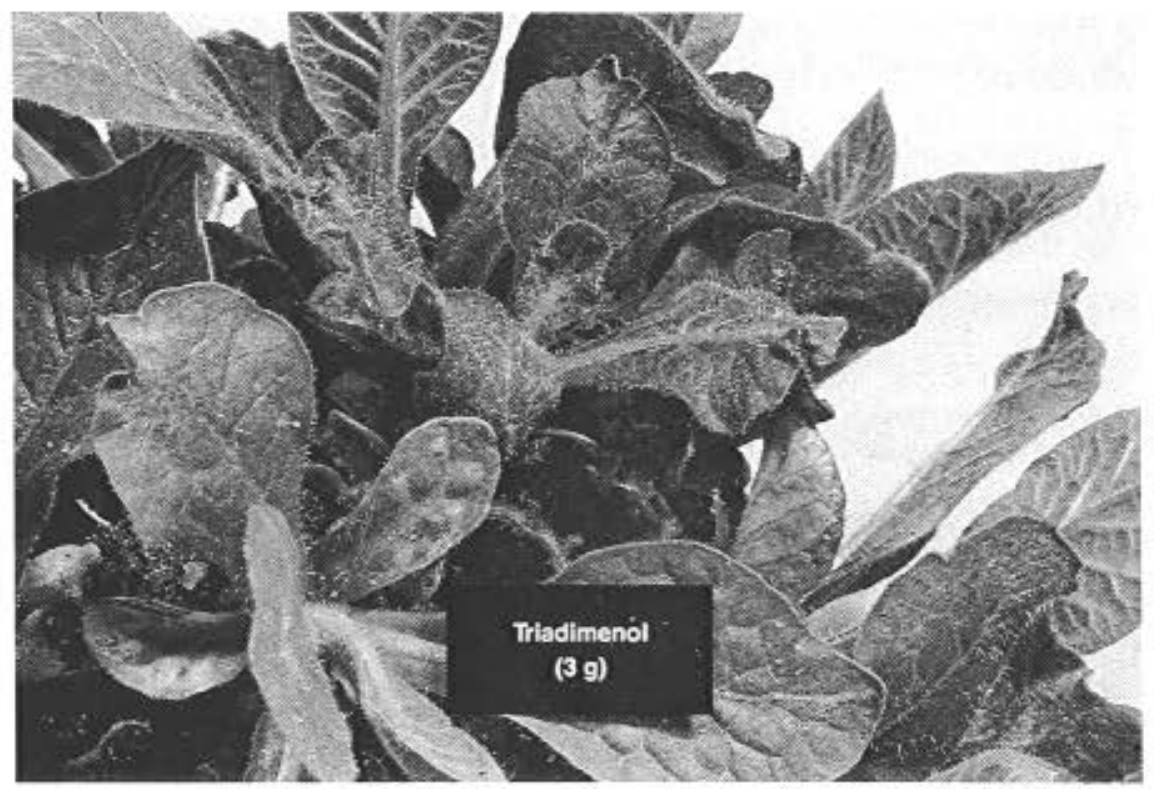




\section{INTRODUCTION}

Chalara elegans (Thielaviopsis basicola), the causal agent of black root rot of tobacco (Nicotiana tabacum), is the second most serious pathogen on French tobacco and is considered to be an increasing problem. This situation is partly due to the increasing cultivation, in our country, of the very susceptible flue-cured cultivar Virgin D. In the absence of resistant flue-cured cultivars adapted to our agroclimatic conditions, the use of fungicides appears to be a method of controlling the disease in infested fields.

Several experiments have shown benzimidazoles $(2,3,7$, $8)$ and triazoles $(11,12)$ to be effective in the fungicidal control of black root rot. The group of systemic triazoles includes several active compounds. One of them, triadimenol, is a broad-spectrum fungicide (6) which is effective for several weeks after application and has low phytotoxicity on tobacco. The use of pesticide drenches, just before transplanting seedlings to the field, seems to be a suitable method to control diseases and pests; MiCHEL (10) proposed such a method in 1959 for application of lindane to protect tobacco against wireworms. More recently, Cole and ZvenYIKa (1) developed a method of controlling Rbizoctonia solani and Fusarium solani by drenching with an aqueous suspension of triadimenol two days before the seedlings were transplanted. We (12) have also demonstrated in laboratory and greenhouse studies that triadimenol effectively controls $C$. elegans and stimulates root growth of susceptible cultivars. Also, such method would allow the culture of cultivars with low resistance to black root rot.

The objectives of the research reported herein were:

1. to determine the phytotoxicity of triadimenol compared to benomyl when applied to young tobacco seedlings, and

2. to determine the effectiveness of triadimenol and benomyl in combatting black root rot, when they are applied immediately before transplanting.

\section{MATERIALS AND METHODS}

The flue-cured tobacco cultivar Virgin D (or Virgin SCR), which is very susceptible to black root rot, was used. The fungicides used were benomyl (Benlate) of $\mathrm{Du}$ Pont de Nemours, France, and triadimenol (Baytan) of Bayer A.G., Leverkusen, West Germany (Table 1).

\section{Seedling Study}

An evaluation of fungicide phytotoxicity was conducted in seedbeds disinfected with methyl bromide following fungicide drenches $\left(11 / \mathrm{m}^{2}\right)$ at different doses on young tobacco plants (two-leaf stage), the leaves then being drenched with clear water $\left(21 / \mathrm{m}^{2}\right)$. Plots had an area of $0.5 \mathrm{~m}^{2}$ with a plant density of 500 to 600 per $\mathrm{m}^{2}$. The experimental design included two replications per treatment. Visual observations for phytotoxicity and plant measurements were made 5, 15 and 29 days after treatment. The effect of the fungicides on the root system was evaluated by weighing the roots of 20 plants per replication (after drying at $100^{\circ} \mathrm{C}$ for 10 hours) 29 days after treatment.

\section{Field Study}

Treatments consisted of: (a) benomyl and triadimenol drenches (either 0.5 or $1.0 \mathrm{~g}$ a.i. ${ }^{*}$ in 21 per $\mathrm{m}^{2}$ ) applied to tobacco plants 2 or 3 days before transplanting (Fig. 1), followed immediately by a drench with clear water $\left(5 \mathrm{l} / \mathrm{m}^{2}\right)$, and (b) dipping the roots in a solution of triadimenol $(2 \mathrm{~g}$ a.i. $/ \mathrm{l})$ for $1 \mathrm{~min}$ at transplanting. One hundred treated plants were transplanted to plots $(1 \mathrm{~m} \times 1 \mathrm{~m})$ with two replications per treatment. The test plots were at the Tobacco Research Institute at Bergerac, in an area known to be infested with the

* active ingredient.

Table 1.

Funglcides used in the experiment.




Table 2.

Phytotoxicity of benomyl and triadimenol

applied to young cv. Virgin D tobacco seedlings (two-leaf stage).

\begin{tabular}{|c|c|c|c|c|}
\hline \multirow{2}{*}{ Fungicide } & \multirow{2}{*}{$\begin{array}{c}\text { Dose } \\
\left(\mathrm{g} \text { a.i. } / \mathrm{m}^{2}\right)\end{array}$} & \multicolumn{3}{|c|}{ Days after treatment } \\
\hline & & 5 & 15 & 29 \\
\hline \multirow{4}{*}{ Benomyl } & 0.5 & 0 & 0 & 0 \\
\hline & 1 & 0 & 0 & 0 \\
\hline & 2 & 0 & 0 & $0^{+}$ \\
\hline & 3 & 0 & 0 & 0 \\
\hline \multirow{4}{*}{ Triadimenol } & 0.5 & . & - & . \\
\hline & 1 & * & - & - \\
\hline & 2 & * & - & .. \\
\hline & 3 & * & $*$ & .* \\
\hline
\end{tabular}

0 : No difference from control.

- : Depressive effect, without deformation of the leaves, greener lamina.

..: Severe symptoms of phytotoxicity, deformations of leaves, greener lamina,

+ : Yellower than control.

Table 3.

Effect of triadimenol and benomyl on rhizogenesis (observations in the seedbed 29 days after treatment).

\begin{tabular}{l|c|c}
\hline Fungicide & $\begin{array}{c}\text { Dose } \\
\left(\mathrm{g} \mathrm{a.i} / \mathrm{m}^{2}\right)\end{array}$ & $\begin{array}{c}\text { Dry weight of the root system } \\
\text { per plant } \\
(\mathrm{g})\end{array}$ \\
\hline Untreated & - & 0.728 \\
Benomyl & 1 & 0.747 \\
Triadimenol & 1 & 1.492 \\
\hline Least significant & & 0.338 \\
difference $(\mathrm{p}-0.05)$ & \\
\hline
\end{tabular}

Figure 4.

Effect of triadimenol and benomyl on rhizogenesis 29 days after treatment.

Plants treated with triadimenol have the most developed root system compared to the control or the benomyl-treated plants.

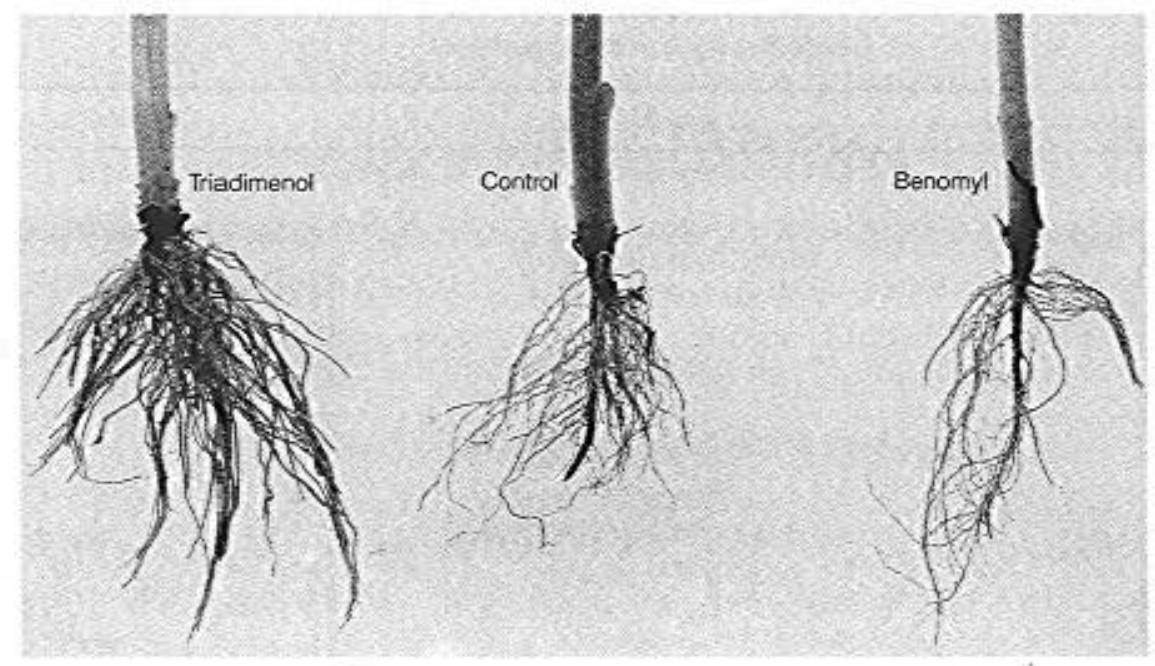


Figure 6.

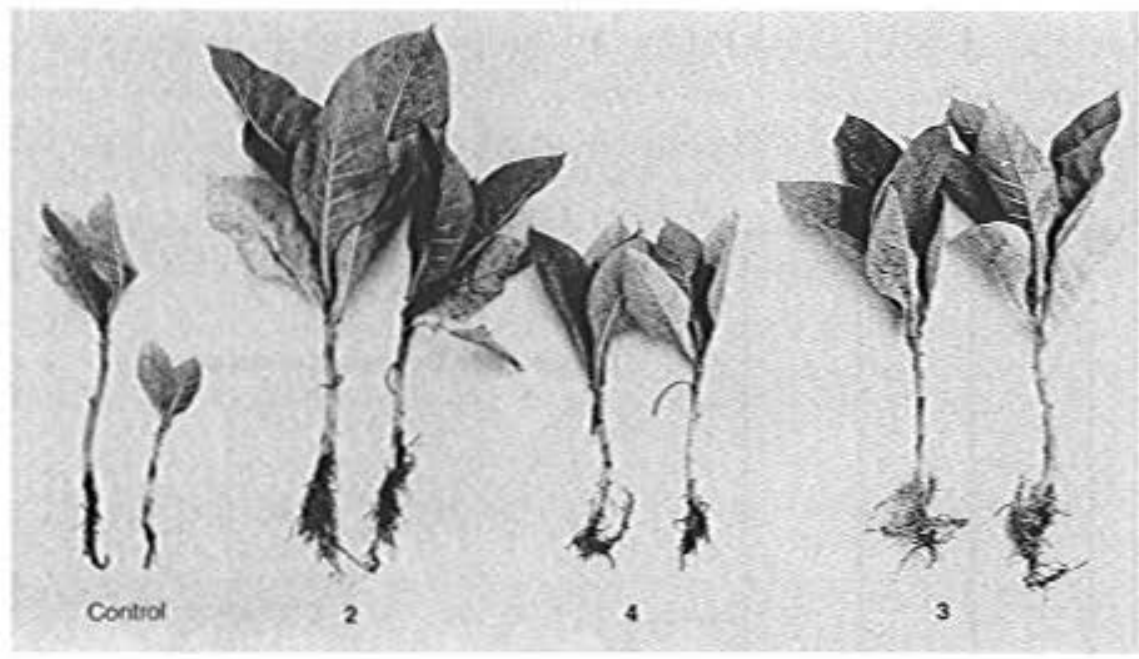

2: Drenching before transplanting with $1 \mathrm{~g}$ triadimenol ai. $/ \mathrm{m}^{2}$,

4: Drenching with $1 \mathrm{~g}$ benomyl a.i. $/ \mathrm{m}^{2}$.

3: Dipping at transplanting for $1 \mathrm{~min}$ in a $2 \mathrm{~g}$ triadimenol// solution.

pathogen. The level of infestation by C. elegans was determined prior to the experiment by the carrot root disc test of Izard and Schiltz (9).

The criterion used to evaluate the effectiveness of the treatments was the vegetative growth rate of tobacco plants, measured by recording the dry weight of aerial parts and root systems 32 and 58 days after transplanting.

\section{RESULTS}

\section{Effect of Benomyl and Triadimenol as regards Phytotoxicity or Root Growth of Tobacco Seedlings}

In disinfected seedbeds, the tobacco seedlings treated with triadimenol at the two-leaf stage were, 5 days after treatment, greener in colour than those treated with benomyl or the untreated control (Table 2). Fifteen days after the chemical drench treatment, the seedlings treated with triadimenol (all doses) were growing slower than the untreated controls. At the higher concentrations ( 2 and $3 \mathrm{~g}$ a.i. $\left./ \mathrm{m}^{2}\right)$, leaves exhibited some deformations. These deformations were still present at the 29th day (Figures 2 and 3). Benomyl did not retard growth or affect leaf morphology. However, at the time of plant extraction (29 days), seedlings treated with triadimenol had the greatest root mass in spite of showing early reduced aerial growth (Table 3 and Fig. 4). These observations confirm the results obtained by Pululu and Delon (12), which showed the rhizogene- sis stimulation of tobacco by triazoles, particularly triadimenol.

These results indicate that only very careful use of triadimenol on very young tobacco seedlings should be practised, especially at higher doses $\left(3 \mathrm{~g} \mathrm{a.i} / \mathrm{m}^{2}\right)$.

\section{Efficacy of Pre-transplant Treatments of Benomyl and Triadimenol on Black Root Rot in the Field}

All treatments with benomyl or triadimenol protected the plants against the disease, but the protection was not complete (Fig. 5). After 32 and 58 days untreated control plants had more infection, as shown by the lighter weights of plants (aerial part or roots), than treated plants. The influence of triadimenol treatment on plant development (aerial parts and roots) was more pronounced after 58 days (Fig. 5). At that time, there was no significant difference between the untreated control and the benomyl-treated plots. Dipping the roots in a triadimenol solution $(2 \mathrm{~g} \mathrm{a.i} / \mathrm{l})$ for $1 \mathrm{~min}$ was less effective than soil drenches; however, the roots appeared to have less damage and necrosis (Fig. 6) than in the other treatments. Further experiments must be conducted to find a more suitable exposure time and dosage rate for the fungicide. After 58 days' growth in infested soil (Fig. 6) plants treated with triadimenol drenches had larger root systems than those from other treatments. However, they did exhibit some blackbrown necrotic lesions, indicating infection by the parasite.

For Figure $\mathbf{5}$ see p. 194. 
Figure 5. Efficacy of benomyl and triadimenol against tobacco black root rot (Virgin D).
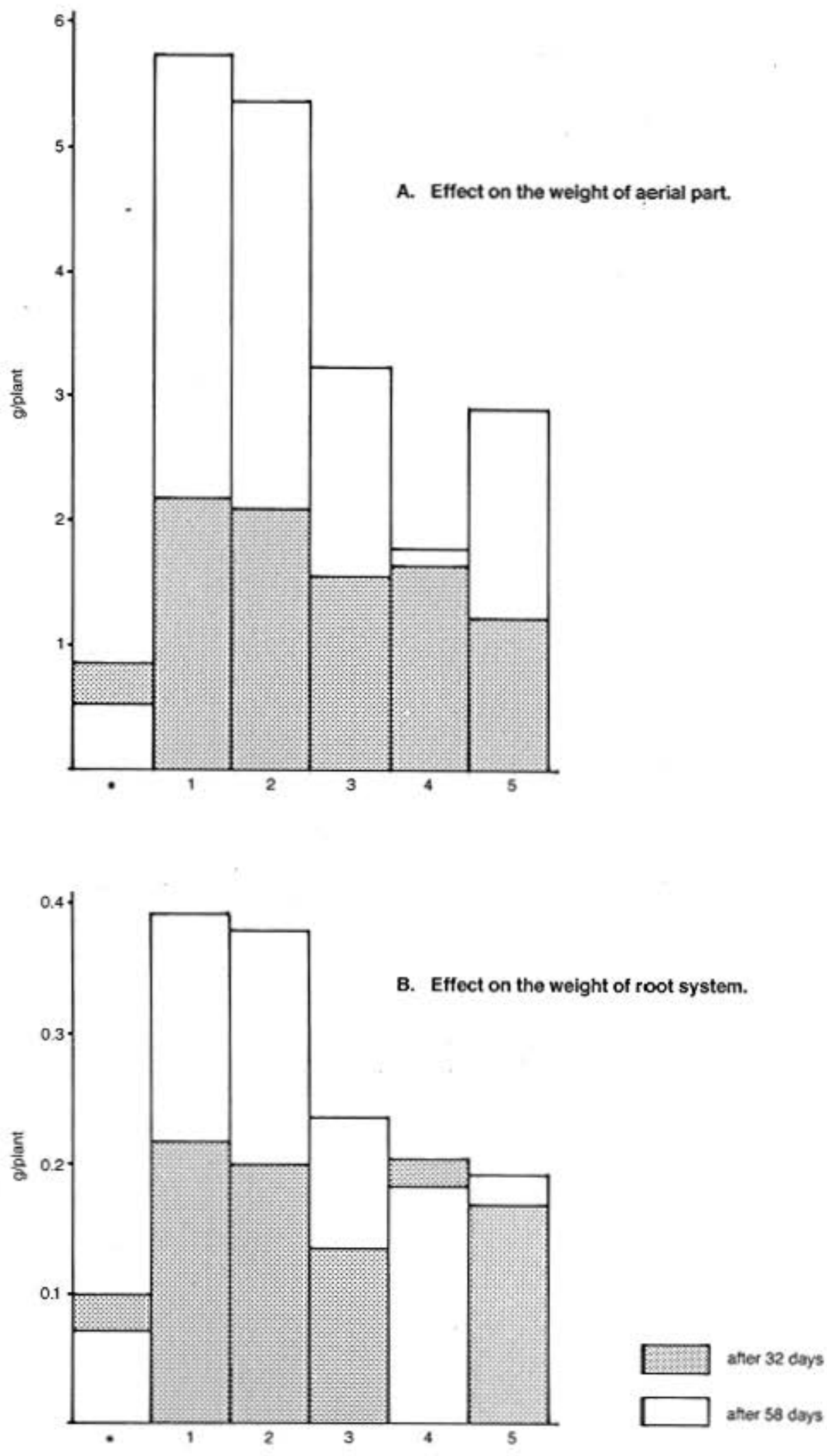

1: Triadimenol - $0.5 \mathrm{~g}$ a.i. $/ \mathrm{m}^{2}$ drenched before transplanting.

2: Triadimenol - $1 \mathrm{~g}$ a.i. $/ \mathrm{m}^{2}$ drenched belore transplanting.

3: Triadimenol - dipping the root system in a solution containing $2 \mathrm{~g}$ a.i. $/ 1$ for $1 \mathrm{~min}$.
4: Benomy - $0.5 \mathrm{~g}$ a.i. $/ \mathrm{m}^{2}$ drenched before transplanting.

5: Benomyl $-1 \mathrm{~g}$ a.i. $/ \mathrm{m}^{2}$ drenched before transpianting.

$\because$ Untreated control 


\section{DISCUSSION}

Although triadimenol gives efficient control, it ondy be phytotoxic in some circumstances (very young plants, high doses ( $\left.3 \mathrm{~g} \mathrm{mi.i} / \mathrm{m}^{2}\right)$ ). Succes! with this fungictde is condizioned by careful attention to dose (no more than $2 \mathrm{~g} \mathrm{ai.} / \mathrm{m}^{2}$ ), drenching the letves with clear water and time of application (2 or 3 days before trassplantirg).

In 1983 and 1984, numerous trials conducted with triadimenol (Bayzen 15 or 5) by French tobacco growers who had black root rot problems, confirmed the benefit of such a method $(4,5)$. Nerertbeless the use of fungicides alone against tobaceo black root rot is not dways sufficient to control the disense in the field. The most practical method still remains the planting of resistant cultivars, if they are available. It is aloo essential to use disease-free transplants, to avoid transplanting into alksline soils, and to follow recommended tobscco rotation schenes where ausceptible cultivars muar be used. Cold, wet, beary soils farour the disease and should also be zroided if possible.

\section{RAFERENCES}

1. Cole, J. S., and Z. Zvenyika: Triadimenol, a plant growth atimulator and fungicide for the control of Rhizoctonia solani and Fusarium soluni in tobaceo transplants; presented at the 8th Int. Tob. Sci. Congr. (coxnsts) beld in Vienna, Austrion in 1984.

2. Corbaz, R.: Progrès recents dans la lutte contre la pourriture noire des racines de tabac; Rev. Suisse Agric. 4 (1972) 110-113.

3. Darid, H. Hsi, and J. R. Melchor Ortiz: Suppression of Thielaviopsis basticale by two fungicides applied to sandy loan soils in New Mexico; Plant Disesse 64 (1980) 1011-1012.

4. Roton, C. de, and R. Delon: Essais de protection du plant contre la pourriture noire des racives; $\mathrm{L}_{2}$ Voix det Cultures 433, 1994, 22-23.

5. Roton, $C$, de, and R, Delon: Protection du plant contre la pourriture noire des racines; France Tabac 3, 1985, 14-16.
6. Frohberger; P. E.: Baytan, a new sysiemic broadspectrum fungicide especially suitable for cereal seed treatment; Pflanzenschutz-Nachr. (Bayer) 31, 1978, 11-24,

7. Gayed, S. K. The effect of sceam compared with fumigants and benomyl on black root rot in tobacco seed-beds; Phytoprotection 57 (1976) $109-115$.

B. Genive, $R$, and F, Cazamajour: Influence de divers agents dessinfectants sur le taux d'infestation dea cols en Thielaviopsis baticola (BarX \& BR.) Frowarus; Ann. Tab. (sema) 7, Section 2 (1970) 153 to 169.

9. Izard, $C_{3,}$ and P. Schiltz: Note sur une technique simple permetrant d'estimer le degré d'infestation d'un sol par Thielaviopsis busicola (Bske. \& $\mathrm{Br}$ ) EkRokers; Inst. Exp. Tabac Bergerac (seTh) 1964, 4 pp., unpublished.

10. Michel, E.: Noureaur essnis contre les larves de taupins - Etude du traitement prealable du plat par arrosage our semis; Ann. Inst. Exp. Tabac Bergerac (sertA) II, No. 2 (1959) 317-332.

11. Prinsloo, G. C.: C.G.A. 64251, an experimeatal systemic fungicide agairst black root rot of tobacco; Pbytophylactica 13 (1981) 49-51.

12. Pululu, M. N., and R. Delon: Actios des trizzoles sur la pourriture noire des racines de tabac (ChaLara elogans] - Comportement dn parasite et de l'bòte; Ann. Tzb. (skrTh) 18, Section 2 (19831984) 151-159.

Antbors" address:

Instituct du sabac Sacizzt nationale d'exploization indusariolle des tabast et allowettes (SEITA), Domaine de La Towr, F-24t00 Bergerac, France. 